\title{
Procurement practices and
}

\section{the municipality auditing market}

\author{
Ana Marques* \\ Nova School of Business and Economics, and \\ Indian Institute of Management Bangalore \\ ana_marques@novasbe.pt
}

Ana Pinto

APPM, SROC, Lda.

anacalado.pinto@appmsroc.pt

The authors appreciate the valuable comments received from Maria João Machado, Benedikt Quosigk and Alex Lyubimov, as well as those received from the participants at the 2016 annual meeting of the AAA, a brown bag at the Indian Institute of Management Bangalore, the 2017 annual meeting of the CAAA, the 2017 JAAF conference, and the 2017 AFAANZ annual conference.

* Corresponding author's address: IIMB, Bannerghatta Road, Bengaluru 560076, India. Tel: +91.8884689903. 


\begin{abstract}
In this study, we perform a comprehensive analysis of municipal auditing, exploring its several steps: procurement, decision on selection criteria, selection, render and payment of services, and opinion provided. Our setting is Portugal, where external auditing of municipalities' accounts has recently been introduced. Our dataset is unique, resulting from merging new survey data with data that is not publicly available. We find that the majority of municipalities acquire auditing services through direct selection and choose their auditors based upon the lowest price selection criterion. However, municipalities which employ a more sophisticated procurement process, where political competition is lower and where citizens' interest is higher, employ the lowest price selection criterion less frequently. The auditor selected is usually a firm (instead of an individual CPA), but never one of the Big 4 companies. The audit fee paid for the auditing services is higher when the level of citizens' interest increases, and lower when the municipality has an internal auditing office. Finally, when the auditor issues a qualified opinion, the auditor fee is also higher.
\end{abstract}

Keywords: local government, political competition, lowest price selection criterion, audit fees, Portugal.

JEL Classification: M41; M42 


\section{Introduction}

Municipalities play an important role in most European countries (Johnsen et al., 2001) as they support development projects directly and cooperate with national governments and European institutions in their plans for growth. A study by the Council of European Municipalities and Regions (2010) indicates that public expenditure by the local sector represents, on average, $13.7 \%$ of the European Union (EU)'s Gross Domestic Product and $27.0 \%$ of its total public expenditure, with a value of $1,676.8$ billion euro in 2010 . Furthermore, public procurement has become more relevant in recent years, as countries face unrelenting budget constraints, government downsizing, and public demand for increased transparency (Thai, 2017).

When municipalities hire auditing firms, they use a procurement process, as required by EU regulation for all acquisitions made by the public sector. Municipalities choose this process as well as its selection criteria. Procurement can be done by direct selection or competitive bidding. Municipalities can select the external auditor which offers the lowest price, or consider technical factors, together with price, in their selection - this is called choosing the most economically advantageous proposal.

In this study, we perform a comprehensive analysis of municipal auditing in Portugal. The number, diverse nature and economic importance of municipalities in Portugal as well as the recent adoption of external auditing and the fact that no Big 4 firm audits the sample municipalities, creates an unique setting for our investigation. We first document whether municipalities use direct selection or competitive bidding as a procurement method. Next, we investigate whether the lowest price selection criterion is generally used by municipalities, and the factors that may determine this choice, as the extensive use of this selection criterion may lead auditing firms to use dumping prices or pressure on the audit time budget. Finally, 
we study audit fees, examining how these change with citizens' interest, the existence of an internal auditing office, and the auditors' opinion. Thus, we explore the several steps of municipality auditing: procurement, decision on selection criteria, selection, render and payment of services, and opinion provided.

The main source of data is a survey conducted by the authors, which was addressed to the heads of financial divisions of all the Portuguese municipalities. From a potential sample of 308 municipalities, we received 57 valid responses, with information regarding local companies' participation (the legal criterion for compulsory external auditing), public procurement practices (procurement process, selection criteria, factors considered in proposals which use the most advantageous proposal criteria, number of tenders), and auditing characteristics (audit fees, auditor type, and existence of an internal auditing office). Our analysis starts in 2007 because that is when external auditing became compulsory for some municipalities. The period of the study comprises five years, ending in 2011.

An initial analysis of the data for the first step of the audit process (procurement) reveals that the majority of municipalities acquire auditing services through competitive bidding. As mentioned, municipalities also choose the selection criteria. We find that most Portuguese municipalities choose their auditors based upon the lowest price selection criterion. Given that sophisticated procurement mechanisms should help identify and hire preferred quality auditors, we first test whether the use of the lowest price selection criterion is associated with procurement sophistication, political competition and citizens' interests. We find that a more sophisticated process is associated with a smaller frequency of selection via the lowest price criterion. This sophistication is measured by three complementarily significant variables: direct selection procurement, length of the auditor's mandate, and number of proposals received. From our logit, we also find that in municipalities with a higher concentration of votes (i.e., where competition is lower), the use of the lowest price 
criterion is less frequent. The third determinant is citizens' interest, measured by government grants, and our results indicate that the value of government transfers is also negatively associated with the use of the lowest price criterion.

Once the proposals come in, municipalities choose their auditor. We find no presence of the Big 4 auditing firms in our sample, which is unusual. The choice of auditor will determine the audit fees to be paid. Our second hypothesis predicts that the audit fees are positively associated with citizens' interest and qualified opinions (as these are may lead to more work) and negatively associated with the existence of an internal auditing office at the municipality (assuming the work of this office is reliable). We find that audit fees are positively associated with citizens' interest, which suggests that an expectation of more scrutiny (due to interest) leads to more audit hours and a higher audit fee. Moreover, the existence of an internal auditing office in the municipality is associated with lower audit fees, indicating that the internal auditors provide valuable assistance to the external auditors. Finally, we find that most of the opinions issued by auditors are qualified opinions, and that these paid are positively associated with audit fees. This suggests that when auditors find some issues of concern in the municipalities' accounts, this leads to a more detailed audit, which is costlier.

This study brings together several strands of the audit literature: (i) audit procurement, (ii) audit fees, (iii) public accounts, and (iv) political competition, while analyzing a unique dataset. Our findings should be of interest to governments and regulators, given the focus on municipalities and the fact that external auditing comes as a consequence of EU regulations. The importance of auditing and its impact on the quality of accounts, combined with the evidence that the lowest price criterion dominates auditor's selection, should lead officials to motivate municipalities to consider other factors (besides price). Finally, our results should be 
of interest to auditors, as our evidence suggests benefits of working with municipalities' internal auditing offices and having longer mandates.

\section{Institutional settings}

The Portuguese Constitution recognizes three types of local governments in Portugal: municipalities, regions, and parishes. Portuguese municipalities promote economic and social development, and can also perform central government functions, if a contract is signed for that purpose. They are responsible for social housing, civil protection, and utilities' infrastructures, among other functions. Additionally, under a contract, they can be responsible for meals provided in public schools, transportation of students, etc.

Municipalities' importance in citizens' lives creates ample interest in their funding and performance. Notwithstanding the existence of direct revenues from taxes, goods, and services, municipalities also participate in the partition of public resources, i.e., central government taxes. A study by the Certified Public Accountants Board (the Annual Financial Directory of Portuguese Municipalities, 2013) notes that Portuguese municipalities receive most of their revenues from the central government, with a financial independence of only $33.7 \%$ (considering the period from 2007 to 2013 ). ${ }^{1}$

The municipal financial system produces both accrual-based and budgetary results, but there is no compulsory reconciliation of the two sets of data. The application of accrual accounting started in 2001. Nevertheless, in the financial year of 2007, according to the annual financial directory of Portuguese municipalities, there were still several mistakes in the application of accrual accounting by many municipalities. Municipality accounts are homologated by the Court of Accounts.

Since the enactment of Law 2/2007, municipalities which own shares in companies (local, municipal, intermunicipal, or commercial), or have a seat in a foundation, need to be 
audited by an external auditor. By the local finances law, a certified public auditor who is named as an external auditor in a municipality must be approved by the municipal assembly, after a compulsory public procurement process. $^{2}$ The first step in the procurement process of auditing services is for municipalities to decide whether they will do it through an open procedure, where all interested firms may submit tenders, or through a restricted procedure, where only invited suppliers may present tenders. The municipality chooses between competitive bidding (open procedure) and direct selection (restricted procedure) ${ }^{3}$ The next step is for municipalities to determine how selection will be done, once the tenders come in. The decision on the selection criterion is done a priori, as it is published in the announcement of the procurement. The selection can be based solely on price, if the decision is to choose the proposal with the lowest price, or consider technical factors in the selection process, which is referred to as choosing the most economically advantageous tender.

As usual, once the audit is complete, the auditor will issue its opinion. This opinion must cover the budget execution, the balance sheet, the profit and loss statement, the notes to the accounts, and any other items required by law or the Municipal Assembly, as the audit is carefully examined by the town council and the assembly. Moreover, once finalized, the auditors' report will be analyzed in the Court of Accounts, which will issue directives (and timelines) for municipalities to solve the issues identified in the auditors' reports. One of the items analyzed is the debt ratio, which is analyzed by the central government. In fact, the local finance law, applicable to municipalities (until 2013), introduced a surveillance method based upon debt ratios, calculated using both accrual and budget accounting data.

\section{Hypotheses development}

\subsection{Need for external auditing in municipalities}


As mentioned, several central government functions have been delegated to municipalities. Nevertheless, it is the central government that responds to the EU. According to agency theory, because it is difficult for the principal to accompany the agent's behavior (information asymmetry), he/she has two options: (i) invest in financial information systems, or (ii) establish a contract with the expected outcomes of the agent's behavior (Eisenhardt, 1989). Both options are implemented in Portugal. First, there is a major platform run by the Local Government Directorate with data retrieved from municipalities on a monthly basis, including budgets, financial issues, personnel, debt ratios, and others. Second, there is a monitoring Council (since 2014) and there are legally binding performance indicators (changed dramatically in 2014). The existence of an external audit is essential to assure the accuracy and relevance of the financial information provided by municipalities, and is the focus of this study.

\subsection{Public procurement}

Well-developed procurement provides relevant information to managers, identifies qualified providers, and aligns organizational needs with the goods or services being purchased (Gansler, 2002). Jensen and Payne (2005) find evidence that municipal managers view audit procurement as a mechanism for regulating audit quality and audit fees, and incorporate it as part of their overall control systems. We refer to a careful and organized process of procurement as sophisticated procurement, and expect such mechanisms to help identify and hire preferred quality auditors, when appropriate selection criteria are chosen by the municipality.

There are several factors that can be used to ascertain the sophistication of the procurement process. The first is the selection criterion that is chosen by the municipality and disclosed at the time the audit procurement is announced. As mentioned before, in Portugal, municipalities may decide to have a competitive bidding (open procedure) or direct selection 
(restricted procedure). We are not aware of any prior literature on the choice of direct selection (versus competitive bidding). Moreover, the fact that the selection criteria is published with the request for proposals also makes this setting different from the selection process of auditors for public companies. We believe the use of direct selection may be an indicator of a more sophisticated process, as the municipalities directly contact a restricted number of providers. The choice of these providers should consider the auditors' experience, reputation, and previous services rendered, so that the most adequate auditors are contacted. ${ }^{5}$ However, it is also possible that managers of municipalities have relationships already established with some auditing firms, which just makes direct selection more convenient, but may bring no advantages for the procurement process.

The second factor that can be used to measure the sophistication of the procurement process is the duration of the mandate, which is disclosed as the number of years covered by the tendering process. A longer mandate reflects a bigger commitment to the auditor chosen and allows the auditor to know the municipality in depth. Thus, a long-term commitment to an auditor should be associated with a more careful choice of an auditor, i.e., one that is not solely based on the lowest price. However, it is also possible that a longer mandate can signal an auditor's entrenchment and complacency, which, especially in cases of high concentration of auditors (i.e., an audit market dominated by the Big 4 firms), can contribute to a more lenient and less skeptical audit for clients, as discussed by Boone et al. (2012).

The third factor that can signal sophistication is the number of tenders received. The number of tenders in the bidding process is considered a common factor to increase competition and leads to a higher administrative burden, especially if the selection criterion is not the lowest price. If the most economically advantageous proposal is selected, in order to identify which auditor must be chosen, all the variables (such as expertise of the team and the detailed working program) must be considered and evaluated. In fact, Tagesson et al. (2015) 
find that Swedish municipalities select from the Big 4 auditors, mostly based on the lowest price. The authors suggest this is simply because other criteria can be subjective and hard to evaluate, while price is simple and objective. Moreover, although litigation risk is generally low in Portugal, as the number of proposals increases, more tenders are involved, so the litigation risk inherent to the legal procedure increases. To avoid or reduce the litigation risk, contractors are compelled to implement additional internal controls. These controls increase the sophistication of the procurement process.

Given that there is tension about the direction of the impact of the first two factors discussed, we state our first hypothesis on the selection criteria in the null form, as follows:

Hla: There is no association between the lowest price selection criterion and public procurement sophistication.

Tagesson et al. (2015) study the impact of competition on the procurement of audit services in the municipal sector of Sweden, and hypothesize that the likelihood that municipalities choose professional auditors based on criteria other than price increases when political competition is strong. The authors' argument is that when political competition increases, the party in power needs to show voters it is acting responsibly and so chooses an audit firm with a good reputation. ${ }^{6}$ However, their results indicate that "competition between political parties did not influence the probability that price would determine the choice of professional auditors". Thus, it is possible that municipalities see political competition as a pressure to have lower costs. This pressure for lower costs, as countries face unrelenting budget constraints, government downsizing, and public demand for increased transparency (Thai, 2017), can lead to a higher importance of price in the selection process. Given these opposing arguments, we do not make a prediction on the direction of the association of these two variables, and state our second hypothesis on the selection criteria as follows: 
H1b: There is an association between the lowest price selection criterion and political competition.

Jensen and Payne (2005) extend the previous literature by introducing the notion that agency costs may serve as a motivating force for organizations to improve their auditprocurement practices. The authors indicate that agency costs are considered via citizen's interests in municipal decisions, which can be measured by their level of economic input (i.e., taxes). They expect a higher level of citizen's interest to be positively associated with a demand for "higher levels of external monitoring, which can be more readily assessed with adequate procurement processes."7 Although Jensen and Payne (2005) proxy for the taxes paid via the median family income of the municipalities, their results indicate this variable is positively associated with procurement sophistication. Thus, agency costs are relevant for the procurement process used by municipalities. Applying this to our context, we expect citizen's interest to be associated with a higher probability of municipalities selecting the most economically advantageous proposal for their auditing services. This way, criteria such as a detailed auditing report which may include recommendation (for example) will be taken into consideration in the selection of the auditor.

Also following an agency theory perspective, Blank et al. (2009) consider citizens as the principal. This rationale makes sense in a country where the municipalities do not receive most of their funds via government transfers - Blank et al. (2009) study Sweden, where government grants are only $13 \%$ of total revenues. However, in Portugal, government grants represent more than $66 \%$ of total revenues. Thus, in Portugal, the central government is an important player in municipalities' finances. This importance is reinforced by the fact that the annual financial directory of Portuguese municipalities develops the concept of municipality's effective autonomy based upon independence from central government 
transfers. Therefore, we must consider citizens' interest in two ways: the taxes paid by individuals and the grants received from the government. We state our third hypothesis on the selection criteria as follows:

H1c: There is a negative association between the lowest price selection criterion and citizens' interest.

\subsection{Audit fees}

Several studies have examined audit fees and identified variables which are associated with them. Simunic (1980) was the first to address the association between audit quality and audit fees in a public company context, whereas Rubin (1988) was the first to address audit fees in a municipal environment. Although there is an extensive literature on audit fees, very few studies focus on the fees paid by municipalities. In fact, Hay et al. (2006) evaluate and summarize a large body of research on audit fees and find only nine studies involving municipalities in New Zealand and the United States, in a total of 147 studies. These authors stress that audit fees are essential to appraise the competitiveness of the audit market, procurement, and independence.

From an agency theory perspective, both the external auditors and the auditors which work in an internal audit office can monitor the municipality, improving the efficiency of public spending. Pilcher et al. (2013) is a case study on Australian police that examines the extent to which the external auditor relies on the work performed by the internal auditing office, considering that the extent of such reliance depends on the two parties being able to communicate efficiently and coordinate their efforts. Their findings show a lack of reliance on the work of the internal auditors, due to: resource issues, lack of communication, and a perceived lack of competence of the internal auditors. Abbott et al. (2012) also assess whether there is an audit fee reduction due to internal audit provided assistance. Their study 
is based on 134 survey responses from Fortune 1,000 firms, and their results indicate that "the amount of internal audit assistance provided (whether by in-house or outsourced internal auditors) is negatively and significantly associated with audit fees".

Although our setting is different from the one of Abbott et al. (2012), as we analyze municipalities' auditing and the requirements for public accounting in Portugal are different from GAAP, we expecting that there is no lack of reliance on the work of the internal auditors of municipalities. Thus, we state our first hypothesis on audit fees as follows:

H2a: Internal auditing is associated with lower audit fees.

Once the auditing service is rendered, the auditing firm issues its report. In case of concerns, the report will include a qualified opinion. The higher the risk of the municipality, the higher is the probability that a qualified opinion is given. Moreover, there may be indirect consequences of auditing risk. One of those consequences is the fact that when the auditor perceives higher risk he/she will want to accumulate a greater amount of evidence, increasing sample size, before providing an opinion (Arens and Loebbecke, 1984). Consistent with this association, Cho et al. (2017) find a negative association between the quality of accruals and both audit hours and audit fees in Korea. Moreover, as mentioned by Palmrose (1986), the circumstances that lead to the qualified opinion may signal an increased risk of adverse actions against the auditor, which also leads to an increase in the desire for assurance. Thus, we expect that when the auditing firm perceives a municipality to be riskier, the amount of evidence collected increases, leading to a higher audit fee.

As mentioned before, Portuguese municipalities started applying accrual accounting in 2001. However, given the lack of auditing, a priori all municipalities would have been seen as risky when auditors first engaged them. Moreover, mistakes in the application of accrual accounting were still prevalent in many municipalities in 2007 . This increases the potential 
risk of the audit, and the probability of qualified opinions. We state our second hypothesis on audit fees as follows:

H2b: A qualified opinion in the auditors' report is associated with higher audit fees.

\section{Methodology}

\subsection{Sample and Data Collection}

The data analyzed in this study start in 2007 , as that is the year when external auditing became compulsory for some municipalities, and end in 2011 , the last complete fiscal year at the time we administered our survey. The general directorate of local administration publishes (in a web platform) municipality consolidated financial information. The data missing from the dgal.pt website are partially recovered using the financial statements published on-line by each municipality. ${ }^{8,9}$ Although our population consists of 308 municipalities, some observations are lost due to missing data on some of the financial variables required for our initial analysis. Thus, data on 303 municipalities $(1,515$ observations, given we cover five years) is used in our initial descriptive analysis.

Our main source of data is a survey, created by the authors and sent to the financial managers of all Portuguese municipalities. There are 64 respondents. However, only 57 of them sent all the information required. These municipalities represent 285 observations $(57 * 5$ years), which are used in our initial descriptive analysis. However, we lose 115 observations as there are municipalities that answered our survey but do not have external auditing (e.g.: Albufeira) and municipalities that do not have external auditing during all the years we cover (e.g.: Aveiro). This reduces the size of the sample available to test our hypotheses on auditing procurement and fees down to 170 observations, which cover 38 municipalities. Table 1 shows how we reach this final sample.

INSERT TABLE 1 ABOUT HERE 
We use our survey to collect information on several variables of interest to our study: selection criteria, the factors considered when the most economically advantageous tender selection criterion is used, the number of tenders, auditor selection process, type of auditor, auditing fees, existence of internal auditing, capital participation, etc. ${ }^{10}$ The initial set of questions was based on the studies of Hackenbrack et al. (2000) and Jensen and Payne (2005). Next, we pre-tested the survey with field experts and made the adjustments deemed necessary. The survey was launched in 2012, and respondents were invited to answer on-line. The on-line design of the questionnaire makes it possible to skip questions that are of no interest, and facilitates the respondent's task of presenting information for each of the five years covered by the study. ${ }^{11}$ Whenever possible the responses received double-checked by us through different public sources, in order to verify the veracity of the answers. ${ }^{12}$ Moreover, the municipal officials, especially directors and chiefs, abide by an ethics code of conduct of the Organization for Economic Co-operation and Development (OECD). Thus, the reliability of the data is high.

The percentage of respondents is $18.8 \%$, considering a population of 303 municipalities during 2007-2011. The existence of non-respondents may be responsible for biased results, if the municipalities which did not respond to the survey have heterogeneous or dispersed characteristics (Stede et al., 2005). To access this issue, we perform a two-factor analysis based upon geographical territorial coverage (district), and political party. We find that the sample is representative along these dimensions. ${ }^{13}$ Thus, the results of this article may be generalizable to the entire population under study, though some care is necessary, due to possible size considerations. ${ }^{14}$

Information regarding municipality characteristics, such as area, and political parties' votes, is obtained through PORDATA, a database of contemporary Portugal organized and developed by the Francisco Manuel dos Santos Foundation, created in 2009. The reported 
statistics are derived from official and certified sources. ${ }^{15}$ As the identification of municipalities with or without external auditor is not publicly available, a formal request to the Portuguese Institute of Statutory Auditors was made in order to acquire information about the municipalities with an external auditor from 2007 to 2011. Information regarding which municipalities own shares (capital participation) in local companies is obtained through the annual financial directory of Portuguese municipalities.

\subsection{Model specifications and related control variables}

4.2.1 Public procurement determinants model. In order to test the three associations stated in our first set of hypotheses, we need to create a measure of the use of the lowest price selection criterion. This information is provided as answer to a question in our survey. The lowest audit fee offer (Lowest_Fee) is the dependent variable of interest, and is created as an indicator variable. This variable is coded as one when the external auditor's selection is based upon the lowest price selection criterion in a public procurement process, and zero when the most economically advantageous proposal is chosen. We estimate the following logit model:

$$
\begin{aligned}
\log (\mathrm{p} /(1-\mathrm{p}))= & \beta_{0}+\beta_{1} \text { Direct_Sel }+\beta_{2} \text { Mandate }+\beta_{3} \text { Prop_Rec }+\beta_{4} \text { Political_Compet }+ \\
& \beta_{5} \text { Grants }+\beta_{6} \text { Tax }+\beta_{7} \text { Size }+\beta_{8} \text { Debt }+\beta_{\mathrm{i}} D_{k}^{\text {year }}
\end{aligned}
$$

The independent variables, which are the determinants of the use of the lowest price selection criterion, can be classified into: (i) public procurement sophistication variables: type of procurement process, mandate and number of proposals received; (ii) political competition; (iii) citizens' interest measures; and (iv) controls.

The public procurement sophistication variables stem from public procurement law. The chosen public procurement process is represented by a dummy variable that identifies whether public procurement direct selection (Direct_Sel) was used, in which case the variable 
was coded as one. If a competitive procedure was used, this variable is coded as zero. The number of years included in the public procurement process can also affect the selection criterion. We measure this with a variable that measures the length of the mandate, which implies the auditor's rotation (Mandate). A higher number of proposals received should be positively associated with the level of sophistication of the procurement process. As the number of proposals increases, contractors are compelled to implement additional internal controls to reduce litigation risk, which increase the sophistication of the procurement process. Thus, we expect to estimate a negative coefficient for the variable Prop_Rec.

Political competition is measured by a Herfindhal index, calculated as the sum of the squared weights of all political parties. The weight of each party is calculated as the number of seats the party has on the town council, divided by the total number of seats. This is a direct result of elections. ${ }^{16}$ We do not make a directional prediction on $\mathrm{H} 1 \mathrm{~b}$, so we have no expectations for the sign of the coefficients estimated for this variable.

To measure citizens' interest, we use two variables: Grants and Tax. Grants is calculated as the natural logarithm of central government transfers. Tax is measured as tax per capita. Thus, Tax measures the economic input given directly by citizens, while Grants measures the overall economic input, given by government. As we predict a negative association between the lowest price selection criterion and citizens' interest, we expect the estimated coefficients of both Grants and Tax to be negative.

The control variables cover two auditee features: size, and risk. ${ }^{17}$ We expect Size to be negatively associated with selection based upon lowest price, larger municipalities should have more sophisticated procedures in place and be more complex to audit. Size is measured by the area of the municipality, in square kilometers. In Portugal, the debt ratio (debt over average revenues) is the municipalities' legal measure of risk, as stated in the local finance laws. Thus, we use it as a proxy for audit risk. Though municipalities with higher levels of 
debt should procure with better care, it is also possible that the lowest price selection criterion may be used to hide the municipalities' financial situation. Therefore, we make no directional prediction for this variable. Finally, to control for possible time effects, a set of dummy variables $D_{k}{ }^{\text {year }}$ is included in our model (excluding the year 2011). The description of all variables is in Appendix A.

4.2.2 Audit fees model. In order to test the three associations stated in our second set of hypotheses, we create a new model, where the value of audit fees is the dependent variable. This is represented by Aud_Fee, the natural logarithm of the value of audit fees. We estimate the following model:

$$
\begin{aligned}
\text { Aud_Fee }= & \beta_{0}+\beta_{1} \text { Internal_Aud }+\beta_{2} \text { Qual_Opinion }+\beta_{3} \text { Grants }+\beta_{4} \text { Tax }+\beta_{5} \text { Size }+ \\
& \beta_{6} \text { Debt }+\mathrm{B}_{7} \text { Auditor_Firm }+\beta_{\mathrm{i}} \mathrm{D}_{\mathrm{k}}{ }^{\text {year }}+\varepsilon
\end{aligned}
$$

The existence of an internal audit office should be negatively associated with audit fees. To measure the impact of this association on audit fees, we use an indicator variable (Internal_Aud), which is coded as one for municipalities with an internal audit office, and 0 otherwise. Qual_Opinion is also an indicator variable, which is coded as one when the auditor issued a report with a qualified opinion (with or without emphasis), and zero otherwise. The existence of a qualified opinion should be associated with the payment of higher fees.

As control variables, we use five variables, four of which were also included in equation 1. As before, we use two variables to measure citizens' interest: Grants and Tax. We expect them to be positively associated with the fees paid by municipalities, as citizens' interest can lead to higher scrutiny, and as a consequence, higher work load for the auditors. We also expect to find a positive association between Size and Debt, and audit fees. This is because auditing a larger or more risky municipality should involve more work hours, leading 
to higher fees. The last control variable is Auditor_Firm, which aims at controlling for the possibility of firms charging higher fees than individuals. Auditor is an indicator variable, coded as one when the auditing services are performed by a company, and zero otherwise. We expect it to have a positive association with audit fees, as there is earlier evidence of firms trying to charge a premium for their auditing services, especially when these are Big 4 firms (e.g.: Deis and Giroux, 1992). Finally, and as in model 1, we include a set of dummy variables to control for time effects.

\section{Findings and discussion}

\subsection{Descriptive statistics and univariate tests}

5.1.1 External Auditing. Compulsory external auditing, for some municipalities, was introduced by law in 2007. External auditing is compulsory when a municipality participates in local municipal, local intermunicipal and commercial companies, and foundations. Data from the Portuguese Institute of Statutory Auditors indicates that in 2007 almost a third of Portuguese municipalities have external auditing (76 out of 227) and in 2008 the number more than doubles (becoming 161), stabilizing in 2010 (when it is 181). We next cross-check this information with municipalities' participation in foundations, local municipal companies, local intermunicipal companies, and commercial companies, which we obtain through our survey. We surveyed several cases in which there is participation in foundations (1 case), local municipal companies (28 cases), local intermunicipal companies (31 cases), and commercial companies (15 cases), without external auditing. So, the results suggest that there are municipalities that do not comply with the law.

In the whole sample, $51 \%$ of the observations are from municipalities that have external auditors, while this percentage is $65 \%$ when it comes to the observations we collect from the survey. To analyze whether participation in companies or foundations is the only 
substantial difference between municipalities with external auditing and municipalities without external auditing, or if there are other statistically significant differences based upon other municipality characteristics, we perform a two-sample t-test for the equality of means for several variables. We analyze Political_Compt, Grants, Tax, Debt, and Size. We apply the test to both the respondents of the survey and population, with or without external auditing. Table 2 indicates there are significant differences between the group with external auditing and the group without external auditing, both in the population, and in the respondents of the survey (suggesting consistency in the population and survey results). In fact, political competition is the only variable where we do not find a significant difference between groups for both the respondents and the population. Given that municipalities with external auditing statistically differ from those which have no external auditing across several dimensions, we conclude it is not only participation in companies or foundations that differentiates these municipalities. This reinforces the need to control for these variables in our multivariate analyses.

\section{INSERT TABLE 2 ABOUT HERE}

5.1.2 Procurement and selection process. Table 3 presents descriptive statistics for procurement and selection process variables. As shown in Panel A, we find that direct selection in a restricted procedure is the municipalities' choice for the procurement process, with minor exceptions. In fact, there are only four observations in our sample which do not use direct selection. ${ }^{18}$ Next, we document that the selection criterion of choice is the lowest price, as over $71 \%$ of observations answer they use this and not the most economically advantageous proposal. This figure is very close to the $72 \%$ of Swedish municipalities that choose audit firms with the lowest bid (Tagesson et al., 2015). 
The number of years covered by the public procurement process ranges from 1 to 4 years (variable Mandate) but, on average, the auditor stays around two years (mean is 2.4) and the procurement process tends to last for the maximum number of years permitted by the procurement process law (median is 3). ${ }^{19}$ The number of proposals received in a tendering process (variable Prop_Rec) has a mean and median of 3, although the proposals have from 1 to 12 tenders in a procurement process. The value of 12 tenders is found in observations where direct selection is not the procurement process. In the subsample where direct selection is used, the maximum number of tenders is seven. Seven is also the maximum number of proposals requested by municipalities (when using direct selection), although the mean value of proposals requested is 3.26 . Finally, we find that more than $75 \%$ of those municipalities get tenders from all the firms contacted.

Municipalities mostly chose an auditor firm, and not an individual auditor - the mean of indicator variable Auditor_Firm is 0.88 . However, while Tagesson et al. (2015) find that in Sweden, the Big 4 auditing firms dominate the auditing of municipalities, we do not find a single Portuguese municipality which is audited by any of the Big $4 .^{20}$ In the survey we also ask municipalities to identify their auditors. Out of the 25 municipalities which disclosed their auditors' names, 10 changed auditors. If we consider that several municipalities do not need an external auditor for all of the five years analyzed and that the duration of the contract could be up to four years in the period covered, this indicates that there is in fact a significant rotation of auditors. The annual audit fees in municipalities range from $2,000 €$ to $36,000 €$. Their median is $12,000 €$, which is very close to the mean. ${ }^{21}$

Finally, we find that most of the opinions issued by auditors are qualified opinions, indicating that the overall quality of municipalities' financial statements is not good. This may be due to the fact that from 2001 (when accrual accounting was introduced) to 2007, municipalities were not audited. Moreover, of the 127 qualified opinions in our sample, 93 
also included an emphasis on some issue. In fact, only 10 observations have a "clean bill of health" for their financial statements, as they received an unqualified opinion, with no emphasis. The remaining observations have a report which is mostly clean, but has at least an emphasis.

Next, we try to better understand what kind of factors influence public procurement selection of external auditing when the most economically advantageous selection criterion is used. Panel B of Table 3 shows that respondents care about the specialization of the auditor (39.1\%), a detailed work plan (23.9\%), and a detailed work report, which also includes suggestions $(21.7 \%)$. We also analyze the number of factors used in each public procurement process: in 19 cases, only one factor for the selection criterion is considered, besides price (41.3\%), and two and four factors as selection criteria have the same weight (23.9\%), with 11 cases each. $^{22,23}$

\section{INSERT TABLE 3 ABOUT HERE}

\subsection{Correlation matrix}

Table 4 shows the Pearson correlations between the variables used in our study, where the figures in bold are correlations that are statistically significant (at a five percent significance level). Results show that Lowest_Fee is negatively correlated with Mandate, Prop_Rec, Political_Compet, and Grants, providing some information about hypotheses H1a, H1b, and H1c. Moreover, we find a positive correlation between Qual_opinion and Aud_Fee. This correlation is consistent with the prediction we make in hypothesis H2b. Finally, the negative correlation between the lowest price selection criterion (Lowest_Fee) and audit fees (Aud_Fee) reinforces Beattie and Fearnley's (1998) opinion that competition over price may lead to low-balling.

INSERT TABLE 4 ABOUT HERE 


\subsection{Multivariate regression}

5.3.1 Public procurement multivariate regression. Table 5 presents the results of estimating four alternative specifications of equation (1), in order to study the determinants of the use of the lowest price selection criterion by municipalities. In model 1.1, all the independent variables are included, as in equation (1). In model 1.2, the variable Direct_Sel is removed, because our descriptive statistics reveal that only four observations use an open bidding, i.e., this variable has low variation. In model 1.3, we include variables that are the result of principal component analysis, considering the three variables that proxy for sophistication and the two that proxy for citizens' interests. Model 1.4 is similar to the previous one, and the only difference is that when running the principal component analysis for sophistication, we do not consider Direct_Sel. ${ }^{24}$ All four specifications have a high percentage of correct predictions, which indicates a good fit to the data.

Hypothesis 1a is stated in the null and regards the association between the lowest price selection criterion and public procurement sophistication (which is measured via three variables: Direct_Sel, Mandate, and Prop_Rec). Results show the estimated coefficients for these variables as well as the coefficients of the two factors created to reflect sophistication (Sophistication 3 and Sophistication_2), are negative and statistically significant. This indicates that (i) a longer mandate leads to a more careful choice of auditor, where factors other than price are considered, (ii) a higher number of proposals received is associated with a more sophisticated selection, possibly due to an increased litigation risk, and (iii) direct selection can be a mechanism to ask auditors with desirable characteristics to make a proposal. Moreover, the fact that Mandate is negatively associated with the lowest price selection suggests that there is no entrenchment or complacency in these auditors, as discussed above and mentioned by Boone et al. (2012). 
Hypothesis $1 \mathrm{~b}$ states there is an association between the lowest price selection criterion and political competition. Our results show that the coefficient estimated for Political_Compt is negative and statistically significant, indicating that higher concentration of the votes is associated with a lower probability of using the lowest price selection criterion. Thus, a lower level of political competition is associated with a selection process which does not rely solely on price.

Hypothesis 1c states there is a negative association between the lowest price selection criterion and citizens' interest (measured by the variables Grants and Tax). Results show that the estimated coefficient for Grants is negative and significant, as expected, indicating that the more the municipalities rely on government transfers, the highest is the probability that they will consider factors other than price in their auditors' selection. However, the coefficient of Tax is not statistically significant. The coefficients of the factor Citizens (result of principal components analysis) are negative and statistically significant, both in model 1.3 and 1.4. However, these coefficients may be driven solely by Grants. Thus, hypothesis H1c is only partially supported.

Results also indicate that there is a size effect, as larger municipalities have a higher probability of using the lowest price selection criterion. As an additional analysis, and to access the existence of multicollinearity in our models, we have run OLS models similar to the other model in Table 5 and estimated the variance inflation factors (VIFs). Results indicate that there are no multicollinearity concerns, as the mean VIF values are $1.49,1.43$, 1.44, and 1.43, respectively. The maximum VIF values for the individual variables are also low: $2.05,1.92,1.90$, and 1.90 , respectively.

INSERT TABLE 5 ABOUT HERE 
5.3.2 Audit fees multivariate regression. Table 6 presents the results of two alternative specifications of equation (2), which analyzes audit fees. The first specification includes all the variables of equation (2), while the second uses Citizens, a factor that results from the principal component analysis of Grants and Tax (as included in Table 5).

Hypothesis 2a states that the existence of an internal auditing office is associated with lower audit fees. Consistent with this expectation, the coefficient estimated for the variable Internal_Aud is negative and statistically significant. This suggests that the internal auditors provide assistance to the external auditors, alleviating their work load, and leading to lower fees. It also indicates the external auditors trust the work performed by the internal auditors. Hypothesis $2 b$ states that municipalities with a qualified opinion pay more for their audit services. The positive and significant estimated coefficients of Qual_Opinion confirm this relation. This suggests that the auditors accumulate a greater amount of evidence, which leads to more billable hours and a higher audit fee..$^{25}$

The estimated coefficients of Grants and Tax are positive and statistically significant as well as the coefficient for Citizens. Thus, higher interest from citizens is associated with higher fees. Results also show the existence of a size effect. An analysis of the geographical location of the larger municipalities reveals these are mostly rural. Thus, the lower fee may be associated with a less complex auditing. Moreover, we find that auditing firms do not receive higher fees than individual auditors. Thus, they do not extract any kind of premium. This is consistent with our finding that there are no Big 4 firms auditing municipalities. Finally, the estimated coefficients of the indicator variables for the years analyzed are never statistically significant. Thus, we conclude that although Portugal was severely hit by the 2008 financial crisis, this did not have a direct impact on the audit fees paid by municipalities. As an additional analysis, in order to access the existence of multicollinearity in our models, we estimate the variance inflation factors (VIFs). Results indicate that there 
are no multicollinearity concerns, as the mean VIF values are either 1.38 or 1.39 , and the VIF values for the individual variables are also low (maximums of 1.97 and 1.90).

\section{INSERT TABLE 6 ABOUT HERE}

5.3.3 Additional analysis. Given that we find, when testing our first hypothesis, that both sophistication and political competition are negatively associated with the use of the lowest price selection criterion, it would be redundant to test if these two variables were associated with price, as a mechanical effect would exist. ${ }^{26}$ However, the relation between sophistication, political competition and audit fees is not clear for the municipalities that do not use the lowest price as their selection criterion. Thus, we next assess these relations. Given the very small size of the sample (just 49 observations), we test the two associations separately, while still considering the control variables included in equation (2). Table 7 presents the results. The first model tests sophistication, using Sophistication_3 (as included in Table 5). The second model includes Political_Compet. Results show that the coefficient for Sophistication_3 is positive and statistically significant. Thus, even when the lowest price is not the selection criterion, sophistication is still associated with a higher audit fee. This indicates some municipalities are willing to bear a cost in order to have a more sophisticated procedure for the selection of their auditor. The coefficient for Political_Compet is negative and statistically significant, indicating that in municipalities with a higher concentration of votes, the price paid for auditing is lower.

\section{INSERT TABLE 7 ABOUT HERE}

In an untabulated analysis we also use the 170 observations considered in Table 6 , considering an indicator variable coded as one when the municipality does not use the lowest price and zero otherwise. Results of such an analysis reveal that the estimated coefficient is positive (0.32) and statistically significant. Thus, although the use of the most economically 
advantageous criterion does not automatically lead to a higher fee, there is an association between the two things.

\section{Conclusion}

In this study, we perform a comprehensive analysis of municipal auditing, exploring its several steps: procurement, decision on selection criteria, selection, render and payment of services, and opinion provided. Our setting is Portugal, where external auditing of municipalities' accounts has recently been introduced. Our dataset is unique, resulting from merging new survey data with data that is not publicly available. The period considered for analysis of data is 2007 to 2011 .

We find that the majority of municipalities acquire auditing services through direct selection and choose their auditors based upon the lowest price selection criterion. However, municipalities where the procurement process is more sophisticated employ the lowest price selection criterion less frequently. The auditor selected is usually a firm (instead of an individual CPA), but never one of the Big 4 companies. The audit fee paid for the auditing services is higher when the level of citizens' interest increases and when the auditors' opinion is qualified, and lower when the municipality has an internal auditing office. Our findings should be of interest to governments and regulators, given the focus on municipalities and the fact that external auditing comes as a consequence of EU regulations. They should also be of interest to professionals working in auditing, and especially those interested in municipalities, as our findings may direct them in a public procurement process.

This article is subject to one limitation that may affect our findings: the number of respondents for this investigation. It is not possible to exclude the possibility of bias resulting from the number of respondents of the survey. The respondents are municipalities with a higher population, and with more revenue related to taxation (and revenues as a whole) than 
the global average. Finally, we must recognize that due to our sample size we are not able to add municipal fixed effects to our models. 


\section{References}

Abbott, L., Parker, S., \& Peters, G. (2012). Audit Fee Reductions from Internal AuditProvided Assistance: The Incremental Impact of Internal Audit Characteristics. Contemporary Accounting Research. 29 (1), 94-118.

Arens, A., \& Loebbecke, J. (1984). Auditing: An integrated approach. Prentice Hall.

AICPA - The American Institute of CPAs. (2014). Procuring Governmental Audit Services.

Baber, W., Brooks, E., \& Ricks, W. (1987). An Empirical Investigation of the Market for Audit Services in the Public Sector. Journal of Accounting Research, 25 (2), 293-305.

Beattie, V. \& Fearnley, S. (1998). Audit market competition: auditor changes and the impact of tendering. The British Accounting Review, 30 (3), 261-289.

Blank, V., Collin, S., Tagesson, T., \& Broberg P. (2009). Explaining Municipal Audit Costs: Considering the Principal. Working papers series in Business studies. Governance, Accounting \& Development, 3, 1-38.

Boone, J., Khurana, I., \& Raman, K. (2012). Audit market concentration and auditor tolerance for earnings management. Contemporary Accounting Research, 29(4), 1171-1203.

Cahan, S. \& Sun, J. (2015). The effects of audit experience on audit fees and audit quality. Journal of Accounting, Auditing \& Finance, 30 (1), 70-100.

Certified Public Accountants Board (OTOC). (2013). Annual Financial Directory of Portuguese Municipalities (Anuario Financeiro dos Municipios Portugueses).

Cho, M., Ki, E. \& Kwon, S. (2017). The effects of accruals quality on audit hours and audit fees. Journal of Accounting, Auditing \& Finance, 32(3), 372-400.

Decree-law 197/1999, of 8 July. Public Procurement. Diario da Republica.

Decree-law 18/2008, of 29 January. Public Procurement. Diario da Republica.

Deis, D. \& Giroux, G. (1992). Determinants of Audit Quality in the Public Sector. The Accounting Review, 67 (3), 462-479.

Eisenhardt, K. (1989). Agency Theory: An Assessment and Review. The Academy of Management Review, 14 (1), 57-74.

Gansler, J. (2002). A Vision of the Government as a World-Class Buyer: Major Procurement Issues for the Coming Decade. Arlington, VA: PricewaterhouseCoopers Endowment for the Business of Government.

GAO - US Government Accountability Office. (1987). CPA. Audit Quality: A Framework for Procuring Audit Services. 
Hackenbrack, K., Jensen, K., \& Payne, J. (2000). The Effect of a Bidding Restriction on the Audit Services Market. Journal of Accounting Research, 38 (2), 355-374.

Hay, D., Knechel W. \& Wong, N. (2006). Audit Fees: A Meta-analysis of the Effect of Supply and Demand Attributes. Contemporary Accounting Research, 23 (1), 141-191.

Jensen, K. \& Payne, J. (2005). The introduction of price competition in a municipal audit market. Auditing: A Journal of Practice and Theory, 24 (2), 137-152.

Johnsen, A., Meklin, P., Oulasvirta, L., \& Vakkuri, J. (2001). Performance auditing in local government: an explanatory study of perceived efficiency of municipal value for money auditing in Finland and Norway. The European Accounting Review, 10 (3), 583-599.

Law 2/2007, of 25 January. Local Finances law. Diario da Republica.

Law 73/2013, of 3 September. Local Finances law. Diario da Republica.

Nielsen, J. \& Hansen, L. (2001). The EU Public Procurement Regime - Does it work? Intereconomics: Review of International Trade and Development, 36, 255-263.

Palmrose, Z. (1986). Auditor fees and auditor size: Further evidence. Journal of Accounting Research, 24 (1), 97-110.

Pilcher, R., Gilchrist D., Singh, H., \& Singh, W. (2013). The Interface between Internal and External Audit in the Australian Public Sector. Australian Accounting Review, 23 (4), 330-340.

Rubin, M. (1988). Municipal Audit Fee Determinants. The Accounting Review, 63 (2), 219-236.

Simunic, D. (1980). The pricing of audit services: Theory and evidence. Journal of Accounting Research, 18 (Spring), 161-190.

Stede, W., Young S., A. \& Chen, C. (2005). Assessing the quality of evidence in empirical management accounting research: the case of survey studies. Accounting, Organizations and Society, 30 (7-8), 655-684.

Tagesson, T., Glinatsi, N. \& Prahl, M. (2015). Procurement of audit services in the municipal sector: the impact of competition. Public Money \& Management, 35 (4), 273-280.

Thai, K. (2017). Global procurement theories and practices: An introduction. Springer.

Ward, D., Elder, R., \& Kattelus, S. (1994). Further evidence on the determinants of municipal audit fees. The Accounting Review, 69 (2), 399-411. 


\section{Footnotes}

1. The total amount of revenues deducted from transfers and financial liabilities against the total amount of revenues ratio is compared to the indicator of financial independence, considered as 50\%.

2. During the period covered in this study, two different public procurement laws for audit services are applied. Until 2008, the decree-law 197/99 was applicable; while from 2008 onwards, the applicable regulation was decree-law 18/2008 (adapted to EU Regulation). As a municipality can contract for one, two, or three-year periods of auditing, through 2007 and 2008, the decree-law 197/99 was the only one applicable. In 2009, either of the two laws could be applied depending on the year (or month) the procurement process started; and in 2010, decree-law 18/2008 was compulsory for all acquisitions.

3. In general, according to Nielsen and Hansen (2001), the European Union can use five different kinds of procurement procedures: (i) Open procedure, in which all interested suppliers may submit tenders; (ii) Restricted procedure: only invited suppliers may present tenders; (iii) Accelerated procedures: restricted to special cases; (iv) Negotiated procedures; (v) Qualification procedure. The negotiated and accelerated procedures in the Portuguese legislation can occur only under very special circumstances, and are not applied to services such as auditing. When the qualification procedure is used, the municipality must, in a second stage, use either a bidding or direct selection, only for a restricted group of qualified tenders. Thus, overall we can either have a case of competitive bidding (open procedure) or direct selection (restricted procedure).

4. The new local finance law (Law 73/2013) enhanced the procedure. Moreover, from 2013 onwards, municipalities are obliged to have an external auditor if their expense budget reaches one million euros.

5. Consistent with this view that experience is relevant in the selection of auditors, Cahan and Sun (2015) find that the experience of auditors in China is negatively associated with earnings management.

6. Blank et al. (2009) do not study procurement (they analyze audit fees), but use an argument similar to Tagesson et al. (2015) when it comes to the importance of competition. The authors mention that when political competition is present, the opposing parties continuously create conflicts and distrust, and systematically raise questions and doubts about the actions of the party in power, and that this environment leads to an increase in the monitoring efforts in auditing and results in extra work for the auditor. Other authors, such as Baber et al. (1987), Deis and Giroux (1992), and Ward et al. (1994), confirm that political competition may influence the external auditing process.

7. Ward et al. (1994) and Baber et al. (1987) also consider the impact of citizens' interest, when analyzing audit fees.

8. Municipalities Amadora (2007 to 2009), Amarante (2007), Bragança (2008), Celorico da Beira (2008), Mesão Frio (2008), Pedrógão Grande (2007), Santa Cruz (2007), and Vila Nova de Cerveira (2007).

9. Municipalities are compelled by the local finance law to publish on-line the last two years of financial statements. It was possible to download data concerning three of the eight municipalities missing, Amarante, Bragança, and Celorico da Beira.

10. The survey is available from the authors, upon request. 
11. Some examples, (i) if asked if there is an internal audit office, a "no" answer skips the question about its hierarchy; (ii) after answering about local companies' participation, the respondent is asked if external auditing services are contracted within the 2007 to 2011 period. If not, the questionnaire ends for this respondent.

12. The procurement process and the mandate of the auditor are examples of information that was double-checked.

13. In terms of geographical representation, we find that only three out of 20 districts are not represented in the survey. Concerning political party representation: only one out of seven political parties (CDS-PP, which is not one of the main parties) is not represented in the responses to the survey.

14. Jensen and Payne (2005) face the same dilemma, so they restrict the population to include only municipalities above 5,000 inhabitants. This is not an option in our case as we also study law compliance with external auditing obligations, which is not dependent upon size.

15. Information retrieved from http://www.pordata.pt/.

16. There were local administration elections in 2005 and 2009. Thus, the values of political competition are stable in 2007, 2008 and 2009, and change for 2010 and 2011 (as a result of the elections).

17. Given that the municipalities which are required to have an external auditor are the most complex ones (due to their participation in companies or foundations), all our municipalities could be classified as complex. Thus, we do need to include an indicator variable to control for the additional fees complex municipalities pay (when compared to the rest).

18. These four observations which use competitive bidding are split evenly when it comes to the selection criteria: two use the lowest price criterion, while the other two select the most economically advantageous proposal.

19. The maximum is four years, as the old law allowed for contracts of four years. One year is the minimum time allowed per law.

20. There are only two cases of second tier multinational firms being explicitly identified. Note that Portuguese auditor's law forbids local companies to adopt international brand names unless the latter participates in the local companies' capital.

21. This value is much lower than the mean value of auditing a public firm. Anecdotal evidence suggests that the low value of the fee is associated with the fact that most auditors are locals (i.e., they are headquartered in the municipality they audit).

22. To identify the factors in the survey, we use factors from the literature review, bids published in journals, and ask professionals in the field to identify the most common factors.

23. Though earlier studies (GAO, 1987; AICPA, 2014) indicate that compliance with standards or seniority of the team are important factors, the respondents do not identify them in their public procurement process.

24. The principal component analysis is performed creating factors with an eigenvalue higher than 1. The Sophistication_3 factor explains 54\% of the variation of the three variables included, while the Sophistication_2 factor explains $65 \%$ of the variation of the two variables included (Mandate and Proposals_Rec). The Citizens factor explains $65 \%$ of the variation of the two variables included (Grants and Tax).

25. It is also possible that there is a risk component to the additional fees.

26. The results of such a model indicate that our coefficients of interest for the fees' model (Grants, Tax, Internal_Aud and Qual_opinion) have the predicted signs and are statistically significant. 
Appendix A - Variables' description

\begin{tabular}{|c|c|c|}
\hline Variable & Description & Source \\
\hline Lowest_Fee & $\begin{array}{l}\text { Criteria for choosing candidates. Indicator } \\
\text { variable coded } 1 \text { when municipality chooses the } \\
\text { audit service provider with the lowest fee, and } 0 \\
\text { otherwise. }\end{array}$ & Survey \\
\hline Direct_Sel & $\begin{array}{l}\text { Procurement method. Indicator variable coded } 1 \\
\text { when municipality uses a restricted procurement } \\
\text { process (direct selection), and } 0 \text { otherwise } \\
\text { (bidding process). }\end{array}$ & Survey \\
\hline Mandate & $\begin{array}{l}\text { Number of years of the mandate of the } \\
\text { procurement process. Range is from } 1 \text { to } 4 .\end{array}$ & Survey \\
\hline Prop_Rec & $\begin{array}{l}\text { Number of proposals received for external } \\
\text { auditing. }\end{array}$ & Survey \\
\hline Political_Compet & $\begin{array}{l}\text { Herfindhal Index, calculated using the weights of } \\
\text { the several political parties. }\end{array}$ & PORDATA \\
\hline Grants & $\begin{array}{l}\text { Natural logarithm of total amount of transfers } \\
\text { originated at Central Government level. }\end{array}$ & $\begin{array}{l}\text { DGAL and } \\
\text { Municipalities } \\
\text { website }\end{array}$ \\
\hline Tax & Tax, per capita. & $\begin{array}{l}\text { DGAL and } \\
\text { Municipalities } \\
\text { website }\end{array}$ \\
\hline Size & Land covered by the municipality. & PORDATA \\
\hline Debt & Ratio of total debt over revenues. & $\begin{array}{l}\text { DGAL and } \\
\text { Municipalities } \\
\text { website }\end{array}$ \\
\hline Aud_Fee & $\begin{array}{l}\text { Audit Fee. Logarithm of price, per year, of the } \\
\text { external auditing services. }\end{array}$ & Survey \\
\hline Internal_Aud & $\begin{array}{l}\text { Indicator variable, coded } 1 \text { when municipality } \\
\text { has an internal auditing office, and } 0 \text { otherwise. }\end{array}$ & Survey \\
\hline Qual_Opinion & $\begin{array}{l}\text { Indicator variable, coded } 1 \text { when municipality } \\
\text { receives a qualified opinion, and } 0 \text { otherwise. }\end{array}$ & Survey \\
\hline Auditor_Firm & $\begin{array}{l}\text { Indicator variable, coded } 1 \text { when auditing is } \\
\text { performed by a company of auditors, and } 0 \\
\text { otherwise (individual auditor). }\end{array}$ & Survey \\
\hline
\end{tabular}


Table 1 - Sample

Population (308 municipalities, 5 years) $\quad 1,540$

Missing data (5 municipalities, 5 years)

Population sample for initial tests

1,515

Survey not answered (239 municipalities, 5 years) $\quad(1,195)$

Incomplete surveys ( 7 municipalities, 5 years)

Survey sample for initial tests

Observations without external auditing

Sample for test of hypotheses

170 
Table 2, Panel A - Comparison of observations from survey, considering the need for an external auditor $(\mathrm{N}=285)$

\begin{tabular}{lrrrr}
\hline & With External & Without External & Survey & \\
& \multicolumn{1}{c}{ Auditor } & Auditor & T-stat & \\
& $(\mathrm{N}=170)$ & $(\mathrm{N}=115)$ & & \\
\hline Political_Compet & 0.50 & 0.51 & -0.98 & $* * *$ \\
Grants & 16.17 & 15.89 & 3.22 & $* * *$ \\
Tax & 230.23 & 213.82 & 0.64 & $*$ \\
Debt & 0.89 & 0.67 & 2.76 & $* * *$ \\
Size & 247.72 & 205.34 & 1.73 & $*$ \\
\hline
\end{tabular}

Table 2, Panel B - Comparison of observations from population, considering the need for an external auditor $(\mathrm{N}=1,515)$

\begin{tabular}{lrccc}
\hline & With External & Without External & Population & \\
& \multicolumn{1}{c}{ Auditor } & Auditor & T-stat & \\
& $(\mathrm{N}=772)$ & $(\mathrm{N}=743)$ & & \\
\hline Political_Compet & 0.52 & 0.51 & 0.21 & $* * *$ \\
Grants & 16.04 & 15.72 & 5.73 & $* *$ \\
Tax & 188.55 & 156.00 & 2.30 & $* * *$ \\
Debt & 0.89 & 0.60 & 4.50 & $* *$ \\
Size & 327.73 & 277.59 & 2.02 & $*$ \\
\hline
\end{tabular}

Notes:

*** p-value lower than $0.01 ; * *$ p-value lower than $0.05 ; *$ p-value lower than 0.10 ;

Political_Compet: Herfindhal Index, calculated using the weights of the several political parties;

Grants: Natural logarithm of total amount of transfers originated at Central Government level;

Tax: Tax, per capita;

Debt: Ratio of total debt over revenues;

Size: Land covered by the municipality. 
Table 3, Panel A - Auditing steps: procurement, selection and opinion $(\mathrm{N}=170)$

\begin{tabular}{lccr}
\hline \multicolumn{1}{c}{ Variables } & Mean & Median & \multicolumn{1}{c}{ Standard } \\
& & & Deviation \\
\hline Direct selection & 0.9765 & 1 & 0.1520 \\
Lowest fee & 0.7118 & 1 & 0.4543 \\
Mandate & 2.3765 & 3 & 1.0712 \\
Proposals received & 3.0471 & 3 & 2.2684 \\
Auditor firm & 0.8824 & 1 & 0.3231 \\
Qual_Opinion & 0.7471 & 1 & 0.4360 \\
\hline
\end{tabular}

Notes:

The maximum value for Mandate is 4 years and the maximum value for Proposals received is 12;

Direct selection: Procurement method. Indicator variable coded 1 when municipality uses a restricted procurement process (direct selection), and 0 otherwise (bidding process);

Lowest fee: Criteria for choosing candidates. Indicator variable coded 1 when municipality chooses the audit service provider with the lowest fee, and 0 otherwise;

Mandate: Number of years of the mandate of the procurement process. Range is from 1 to 4;

Proposals received: Number of proposals received for external auditing;

Auditor firm: Indicator variable, coded 1 when auditing is performed by a company of auditors, and 0 otherwise (individual auditor);

Qual_Opinion: Indicator variable, coded 1 when municipality receives a qualified opinion, and 0 otherwise.

Table 3, Panel B - Factors considered in procurement, besides price $(\mathrm{N}=49)$

\begin{tabular}{lcc}
\hline \multicolumn{1}{c}{ Factors } & $\mathrm{N}$ & $\%$ \\
\hline Specialization in field & 20 & $40.8 \%$ \\
Standards' compliance & 0 & $0.0 \%$ \\
Team competence & 0 & $0.0 \%$ \\
Detailed work plan & 11 & $22.4 \%$ \\
Detailed report & 10 & $20.4 \%$ \\
Other - not explained & 8 & $16.3 \%$ \\
\hline
\end{tabular}


Table 4 - Correlation matrix $(\mathrm{N}=170)$

\begin{tabular}{|c|c|c|c|c|c|c|c|c|c|c|c|c|c|}
\hline & 1 & 2 & 3 & 4 & 5 & 6 & 7 & 8 & 9 & 10 & 11 & 12 & 13 \\
\hline Lowest_Fee (1) & 1 & & & & & & & & & & & & \\
\hline Direct_Sel (2) & 0.073 & 1 & & & & & & & & & & & \\
\hline Mandate (3) & -0.238 & -0.163 & 1 & & & & & & & & & & \\
\hline Prop_Rec (4) & -0.389 & -0.443 & 0.302 & 1 & & & & & & & & & \\
\hline Political_Compet (5) & -0.166 & 0.119 & -0.206 & -0.238 & 1 & & & & & & & & \\
\hline Grants (6) & -0.251 & -0.214 & 0.234 & 0.346 & -0.448 & 1 & & & & & & & \\
\hline $\operatorname{Tax}(7)$ & -0.002 & -0.139 & 0.011 & 0.110 & -0.302 & 0.306 & 1 & & & & & & \\
\hline Size (8) & 0.177 & 0.105 & -0.048 & -0.182 & 0.024 & 0.065 & -0.036 & 1 & & & & & \\
\hline Debt (9) & -0.082 & 0.020 & 0.001 & -0.145 & 0.111 & -0.036 & -0.012 & -0.043 & 1 & & & & \\
\hline Aud_Fee (10) & -0.364 & -0.158 & 0.170 & 0.236 & -0.228 & 0.497 & 0.331 & -0.126 & 0.019 & 1 & & & \\
\hline Internal_Aud (11) & -0.085 & -0.024 & 0.177 & 0.119 & -0.324 & 0.087 & 0.352 & -0.147 & 0.010 & -0.049 & 1 & & \\
\hline Qual_Opinion (12) & -0.042 & -0.001 & 0.154 & 0.048 & -0.220 & -0.046 & 0.076 & -0.132 & 0.181 & 0.201 & -0.022 & 1 & \\
\hline Auditor_Firm (13) & -0.031 & 0.184 & 0.043 & -0.009 & 0.040 & 0.215 & 0.143 & 0.107 & -0.045 & 0.210 & -0.130 & 0.40 & 1 \\
\hline
\end{tabular}

Notes: Correlation in bold are statistically significant, at a 5\% confidence level; all variables defined on Appendix A. 
Table 5 - Equation (1): Logit regression analysis on Lowest_Fee $(N=170)$

\begin{tabular}{|c|c|c|c|c|c|c|c|c|}
\hline & \multicolumn{2}{|c|}{ Model 1.1 } & \multicolumn{2}{|c|}{ Model 1.2} & \multicolumn{2}{|c|}{ Model 1.3} & \multicolumn{2}{|c|}{ Model 1.4} \\
\hline & Coeff. & p-value & Coeff. & p-value & Coeff. & p-value & Coeff. & p-value \\
\hline Direct_Sel & -3.425 & 0.021 & & & & & & \\
\hline Mandate & -0.695 & 0.005 & -0.603 & 0.010 & & & & \\
\hline Proposals_Rec & -0.451 & 0.000 & -0.320 & 0.001 & & & & \\
\hline Sophistication_3 & & & & & -0.784 & 0.001 & & \\
\hline Sophistication_2 & & & & & & & -1.124 & 0.000 \\
\hline Political_Compet & -11.597 & 0.000 & -11.091 & 0.000 & -8.352 & 0.000 & -10.119 & 0.000 \\
\hline Grants & -1.462 & 0.001 & -1.475 & 0.001 & & & & \\
\hline Tax & 0.000 & 0.930 & 0.001 & 0.612 & & & & \\
\hline Citizens & & & & & -0.574 & 0.004 & -0.646 & 0.002 \\
\hline Size & 0.004 & 0.021 & 0.004 & 0.029 & 0.002 & 0.049 & 0.003 & 0.038 \\
\hline
\end{tabular}




\begin{tabular}{|c|c|c|c|c|c|c|c|c|}
\hline Debt & -0.486 & 0.169 & -0.596 & 0.083 & -0.391 & 0.214 & -0.454 & 0.169 \\
\hline Year FE & Included & & Included & & Included & & Included & \\
\hline Constant & 36.339 & 0.000 & 32.699 & 0.000 & 5.012 & 0.000 & 5.906 & 0.000 \\
\hline LR p-value & 0.000 & & 0.000 & & 0.000 & & 0.000 & \\
\hline Correct prediction & $82 \%$ & & $81 \%$ & & $76 \%$ & & $80 \%$ & \\
\hline Pseudo $\mathrm{R}^{2}$ & 0.356 & & 0.330 & & 0.219 & & 0.292 & \\
\hline
\end{tabular}

Notes:

Lowest fee: Criteria for choosing candidates. Indicator variable coded 1 when municipality chooses the audit service provider with the lowest fee, and 0 otherwise; Direct selection: Procurement method. Indicator variable coded 1 when municipality uses a restricted procurement process (direct selection), and 0 otherwise;

Mandate: Number of years of the mandate of the procurement process. Range is from 1 to 4;

Proposals_Rec: Number of proposals received for external auditing;

Sophistication_3: factor resulting from principal component analysis of the three sophistication variables;

Sophistication_2: factor resulting from principal component analysis of two sophistication variables;

Political_Compet: Herfindhal Index, calculated using the weights of the several political parties;

Grants: Natural logarithm of total amount of transfers originated at Central Government level;

Tax: Tax, per capita;

Citizens: factor resulting from principal component analysis of Grants and Tax;

Size: Land covered by the municipality;

Debt: Ratio of total debt over revenues. 
Table 6 - Equation (2): OLS regression analysis on audit fees $(N=170)$

\begin{tabular}{lcccc}
\hline & \multicolumn{2}{c}{ Model 2.1 } & \multicolumn{2}{c}{ Model 2.2 } \\
& Coeff. & p-value & Coeff. & p-value \\
\hline Internal_Aud & $\mathbf{- 0 . 1 9 9}$ & $\mathbf{0 . 0 0 4}$ & $\mathbf{- 0 . 2 3 3}$ & $\mathbf{0 . 0 0 1}$ \\
Qual_Opinion & $\mathbf{0 . 2 3 8}$ & $\mathbf{0 . 0 1 9}$ & $\mathbf{0 . 2 2 1}$ & $\mathbf{0 . 0 2 7}$ \\
Grants & 0.328 & 0.000 & & \\
Tax & 0.001 & 0.003 & & \\
Citizens & & & 0.267 & 0.000 \\
Size & -0.000 & 0.004 & -0.000 & 0.004 \\
Debt & -0.027 & 0.729 & -0.029 & 0.717 \\
Auditor_firm & 0.111 & 0.527 & 0.113 & 0.515 \\
Year FE & Included & & Included & \\
Constant & 3.805 & 0.000 & 9.362 & 0.000 \\
\hline Adj. R & $33.94 \%$ & & $32.80 \%$ & \\
p-value of F-stat & 0.000 & & 0.000 & \\
\hline
\end{tabular}

Notes:

Audit Fees: Logarithm of price, per year, of the external auditing services;

Internal_Aud: Indicator variable, coded 1 when municipality has an internal auditing office, and 0 otherwise.

Qual_Opinion: Indicator variable, coded 1 when municipality receives a qualified opinion, and 0 otherwise;

Grants: Natural logarithm of total amount of transfers originated at Central Government level;

Tax: Tax, per capita;

Citizens: factor resulting from principal component analysis of Grants and Tax;

Size: Land covered by the municipality;

Debt: Ratio of total debt over revenues;

Auditor firm: Indicator variable, coded 1 when auditing is performed by a company of auditors, and 0 otherwise (individual auditor). 
Table 7 -Sub-sample where municipalities choose the most economically

advantageous proposal $(N=49)$

\begin{tabular}{lcccc}
\hline & Coeff. & p-value & Coeff. & p-value \\
\hline Sophistication_3 & $\mathbf{0 . 1 1 7}$ & $\mathbf{0 . 0 1 2}$ & & \\
Political_Comp & & & $\mathbf{- 1 . 8 5 0}$ & $\mathbf{0 . 0 0 0}$ \\
Size & -0.001 & 0.159 & -0.001 & 0.064 \\
Debt & -0.048 & 0.670 & -0.147 & 0.123 \\
Auditor_firm & -0.092 & 0.634 & -0.066 & 0.612 \\
Year FE & Included & & Included & \\
Constant & 9.851 & 0.000 & 11.029 & 0.000 \\
\hline Adj. R ${ }^{2}$ & $2.31 \%$ & & $32.07 \%$ & \\
p-value of F-stat & 0.000 & & 0.015 & \\
\hline
\end{tabular}

Notes:

Sophistication_3: factor resulting from principal component analysis of the three sophistication variables;

Political_Compet: Herfindhal Index, calculated using the weights of the several political parties;

Size: Land covered by the municipality;

Debt: Ratio of total debt over revenues;

Auditor firm: Indicator variable, coded 1 when auditing is performed by a company of auditors, and 0 otherwise (individual auditor). 